190, 589; 1961). Article 6 of the Amended Order enables the Cotton Board to collect from the man. made fibres section of the industry 11 per cent of the total being collected from the whole industry, which in 1959-60 and 1960-61 was $£ 385,000$. For 1961-62 the total proposed to be collected from the industry for all the Cotton Board's activities was $£ 400,000$, of

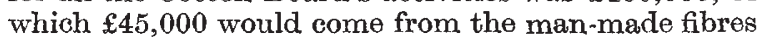
section, and, with $£ 200,000$ from the cotton section, would go to the Research Association. The Order also enables the Cotton Board to assist scientific research on the man-made fibres side. In reply to a question, Mr. N. Macpherson, Parliamentary Secretary to the Board of Trade, who moved the approval of the Order, said that one object of the merger was to reduce expenditure; the income of the Shirley Institute was $£ 462,000$ in $1959-60$ and was expected to be $£ 531,000$ in the first year of the next quinquennium: that of the Rayon Research Association had been $£ 376,000$.

\section{The Devon Naturalists' Trust}

THE Devon Naturalists' Trust was formally inaugurated on March 27. Its objects are to conserve the wild-life of the county against encroachment, to protect places of interest to naturalists, and to encourage the study of natural history. Lord Roborough is the first president. A public meeting to invite support was held in Exeter on May 16, and the speakers were Lord Roborough, Lord Hurcomb, Mr. H. G. Hurrell and Major J. Coleman-Cooke. Mr. Hurrell announced his gift to the Trust of Lady's Wood, its first reserve. This is an area of some 9 acres near South Brent which contains much of interest, including dormice and wood anemones. Apart from the reserve given by Mr. Hurrell, there is a strong possibility that the Trust will be offered another. It is also in contact with a farmer who has a large colony of Lobelia urens on his land, and it is hoped to do something to preserve this very rare plant. The Trust and the Devon Wild Fowlers Association are aeting together to see if the management of the bird sanctuary on the River Exe can be improved. The prospects of introducing blackgame and Zostera marina in suitable places is being studied and may be put in hand if the initial inquiries indicate a good chance of success. The Trust is also making inquiries to discover if the commercial primrose picking reported in the Press last spring is likely to be damaging.

\section{Conservation of Askham Bog}

THE Nature Conservancy and the Yorkshire Naturalists' Trust have agreed to conserve Askham Bog. This area, near York, is a 100-acre remnant of a swamp which must at one time have covered much of the Vale of York. Now almost wholly covered by a thicket of birch, oak and alder, the Bog illustrates the later stages in the succession from open fen to woodland. The ground vegetation includes many bog and fon species uncommon in Yorkshire, among them the rare royal fern. Associated with this flora is a rich variety of insects, particularly beetles. The land is partly owned and partly leased by the Yorkshire Naturalists' Trust, which manages it as a nature reserve. At present it is managed successfully with due regard to the scientific interest and, accordingly, the Nature Conservancy does not feel it necessary to acquire a direct interest in the Bog or to declare it as a National Nature Reserve. By the agreement, Askham Bog is designated a Site of Special Scientific Interest
$(A)$. The Bog will continue to be managed by the Yorkshire Naturalists' Trust, advice from the Nature Conservancy being available when necessary. Permits to visit the site or undertake research there must be obtained from the chairman of the Management Committee, Mr. C. J. Smith, 7 Malton Way, Clifton, York.

\section{Aerial Photographs in Geological Mapping}

IN the construction of geological maps, increasing use has been made in recent years of photo-geology, and to-day even the most junior research student tends to regard aerial photographs as a pre-requisite to his field work. Notwithstanding an extensive periodical literature, however, comprehensive and up-to-date text-books on this subject have been generally unavailable, and geologists throughout the world will therefore be indebted to Dr. Richard G. Ray, of the United States Geological Survey, who has produced an excellent monograph, Aerial Photographs in Geologic Interpretation and Mapping (United States Department of the Interior: Geological Survey. Professional Paper No. 373. Pp. vi+230. Washington, D.C.: Government Printing Office, 1960. 2 dollars). This well-produced prestige publication, sold at a nominal price, lucidly describes the photogeological techniques employed not only in routine geological work but also in the search for petroleum and ore deposits, in engineering geology, and in hydrological investigations; and it furnishes a readable account of the instrumentation utilized in these studies. The text is illustrated by 116 figures, principally stereoscopic-pair photographs chosen from the collections of Government departments in the United States.

\section{The Australian Museum, Sydney}

Tне Australian Museum Magazine (13, No. 9; March 15, 1951. 3s.) includes an account of new aboriginal exhibits which have recently been placed on display in the Museum. One of the most successful of the exhibits illustrates how the aborigines make and use stone implements. Each technical process is demonstrated by using actual implements in cast hands and the impression is given of a native standing behind the exhibit and poking his arms through holes in the wall. The section on "Dress and Orna" ment" appeals to all visitors, and models of the various types of wind-breaks and huts, together with a painting of a camp scene, are equally arresting. The exhibits have been especially designed to be attractive and interesting to the casual visitor, instructive to those wishing to learn about the aborigine, and of service in the Schools Department. Other articles in this interesting Magazine deal with the gem-stones of Australia, fossil insects, freak fishes and the use of radioactivity in entomology and insectpest control.

\section{Site for Ulster Folk Museum}

ThE Trustees of the Ulster Folk Museum have announced the purchase of the Cultra Manor Estate in County Down for the purposes of a site for a permanent folk museum. It includes a manor house and 136 acres of delightfully situated land overlooking Belfast Lough and the Antrim coast. The estate is about six miles from the centre of Belfast and is in an area unlikely to suffer from suburban development. Initial work on the land will start in the summer, and as much material for the Museum 